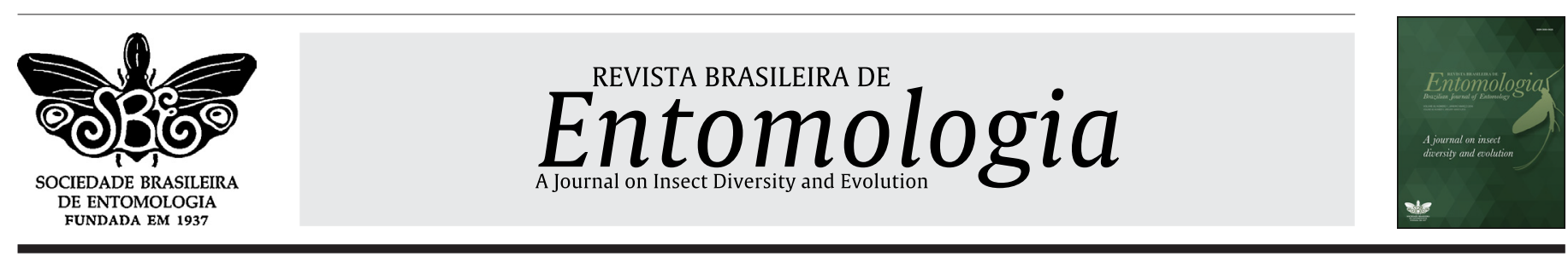

\title{
Biological aspects of Caligo teucer (Lepidoptera: Nymphalidae) with banana tree leaves
}

\author{
Carlos Alberto Domingues da Silva ${ }^{1 *}$ (D), José Cola Zanuncio² ${ }^{2}$ Wiane Meloni Silva³, \\ Luis Carlos Martínez ${ }^{3}$, Fabrício Fagundes Pereira ${ }^{4}$, Germano Leão Demolin Leite ${ }^{5}$ \\ ${ }^{1}$ Embrapa Algodão, Laboratório de Entomologia, Campina Grande, PB, Brasil. \\ ${ }^{2}$ Universidade Federal de Viçosa, Departamento de Entomologia/BIOAGRO, Viçosa, MG, Brasil. \\ ${ }^{3}$ Universidade Federal de Viçosa, Departamento de Engenharia Florestal, Viçosa, MG, Brasil. \\ ${ }^{4}$ Universidade Federal da Grande Dourados, Faculdade de Ciências Biológicas e Ambientais, Dourados, MS, Brasil. \\ ${ }^{5}$ Universidade Federal de Minas Gerais, Instituto de Ciências Agrárias, Insetário G. W. G. de Moraes, Montes Claros, MG, Brasil.
}

\section{A R T I C L E I N F O}

Article history:

Received 07 June 2021

Accepted 26 November 2021

Available online 04 February 2022

Associate Editor: Lucas Kaminski

\section{Keywords:}

Banana tree

Biology

Butterfly

Development stages

Survival

\begin{abstract}
A B S T R A C T
Caligo teucer (Linnaeus, 1758) is widely distributed in Argentina, Bolivia, Brazil and Ecuador. The objective was to study biological aspects of Caligo teucer japetus Stichel, 1903 with banana leaves, Musa sapientium L. (Zingiberales: Musaceae), in the butterfly garden, under environmental conditions, and in the laboratory of biological control of insects at the Universidade Federal de Viçosa in Viçosa, Minas Gerais state, Brazil at $24 \pm 2{ }^{\circ} \mathrm{C}, 68 \pm 10 \%$ relative humidity and 12 hours photophase. The duration of the egg incubation, larvae, pupa and egg to adult periods of C. teucer japetus were, respectively, $11.8 \pm 0.1 ; 53.9 \pm 0.9 ; 17.9 \pm 0.3$ and $82.6 \pm 1.0$ days for females, and $11.8 \pm 0.1$; $50.3 \pm 0.6 ; 18.4 \pm 0.3$ and $79.4 \pm 0.6$ days for males in cages in the laboratory. The longevity of $C$. teucer japetus adults was $26.0 \pm 10.4$ and $47.5 \pm 8.7$ for females and $24.7 \pm 3.5$ and $35.4 \pm 15.7$ for males in the butterfly garden and in laboratory cages, respectively. The high survival and the relatively short period of development of its immature stages confirm that banana leaves are an adequate food substrate for the development and survival of Caligo teucer japetus.
\end{abstract}

\section{Introduction}

Banana, Musa sapientium L. (Zingiberales: Musaceae) is the most consumed tropical fruit in the world and the main product of the international fresh fruit trade (Almeida and Gherardi, 2018). The banana tree is cultivated in several countries, with Brazil, China, Ecuador, the Philippines and India being the largest producers (Silva and Cordeiro, 2000; Fancelli, 2012). In Brazil, this crop ranks second in planted area (458,871 ha) and production $(6,789,420$ tons) among the cultivated fruits (IBGE, 2020).

Pest insects damage plants of the banana $M$. sapientum, some of which with constant presence and wide geographical distribution (Ostmark, 1974; Smilanich and Dyer, 2012). However, the occurrence of most of these pests is regionalized (Labou et al., 2017), increasing the importance of studying their biology and ecology, for the adoption of integrated management measures (Okolle et al., 2011).

\footnotetext{
* Corresponding author.

E-mail: carlos.domingues-silva@embrapa.br (C.A.D. Silva).
}

The genus Caligo Hübner, [1819] (Satyrinae, Brassolina) has 21 species, all of large size (over $100 \mathrm{~mm}$ in wingspan), the majority of twilight habit and gregarious larvae in the initial stages (Penz et al., 1999; Casagrande and Mielke, 2000; Casagrande, 2002). Most studies with these species were on systematic (Wahlberg et al., 2003; Freitas and Brown, 2004; Mielke and Casagrande, 2006; Penz, 2007) and morphology (Souza et al., 2006; Casagrande and Mielke, 2008).

Caligo teucer(Linnaeus, 1758) (Lepidoptera: Nymphalidae) is widely distributed in Argentina (Arroyo and Rodriguez, 2005), Bolivia (Blandin and Descimon, 1975), in the Amazonian region of Ecuador (Devries and Walla, 2001) and in Brazil (Ramos, 2000). Caligo teucer japetus Stichel, 1903, the subspecies that occurs in extra-Amazonian Brazil, damaged Alpinia purpurata (Zingiberaceae), Canna indica (Cannaceae) and Heliconia bihai(Heliconiaceae) plants in the municipalities of Pombos and Recife, Pernambuco state, Brazil (Souza et al., 2006).

The objective of our work was to study the survival and duration of the immature stages of $C$. teucer japetus, with its larvae feeding on banana leaves in the laboratory and, after reaching adult stage, to 
determine its survival and longevity under a butterfly garden and at the laboratory.

\section{Material and Methods}

The work was carried out at the butterfly garden and at the Laboratory for Biological Control of Insects/BIOAGRO at the Federal University of Viçosa (UFV) in Viçosa, Minas Gerais, Brazil. The immature stages of $C$. teucer japetus was studied in a climatic chamber with a temperature of $24 \pm 2{ }^{\circ} \mathrm{C}, 68 \pm 10 \%$ relative humidity and a 12-hour photophase. However, the survival and longevity of adults were studied in a non-acclimatized room of the aforementioned laboratory and in the butterfly garden under similar climatic conditions (temperature of $24 \pm 5{ }^{\circ} \mathrm{C}$, relative humidity of $70 \pm 10 \%$ and photophase of 12 hours).

Seventy-six C. teucer japetus eggs were collected on $M$. sapientium (banana tree) leaves at the UFV Science Park butterfly garden and placed in Petri dishes until the larvae hatched which were individualized in transparent plastic $500 \mathrm{ml}$ pots with a lid and fed daily with pieces of banana leaves until pupae is formed. Specimens of $C$. teucer japetus are not native to the municipality of Viçosa, MG and they were probably introduced from another region of Brazil in the butterfly collection of the aforementioned butterfly garden. The lid of these plastic pots was perforated twice to facilitate aeration and to increase their internal humidity. The aeration orifice (four centimeters in diameter) was sealed with voile fabric and a $2.5 \mathrm{ml}$ plastic tube with distilled water was inserted into the other. Pieces of banana leaves were washed with $5 \%$ aqueous sodium hypochlorite solution before being offered, daily, to $C$. teucer japetus caterpillars.

The pupae of $C$. teucer japetus were sexed, weighed, separated into pairs, fixed in strips of filter paper and kept in wooden cages
(40 cm x $40 \mathrm{~cm}$ x $40 \mathrm{~cm}$, respectively, in width, height and length) until emergence of adults.

Twenty pairs of $C$. teucer japetus were separated, half in the butterfly garden and half in ten laboratory cages. These adults confined in cages were fed with decomposing banana fruits and water (Bauerfeind et al., 2007) and those in the butterfly garden with fermented fruit, in addition to sap from different plants, manure and mineral salts from puddles (Srygley and Penz, 1999). The forewings of the pairs confined in the butterfly garden were marked with overhead projector ink to facilitate their differentiation during the observations.

The duration and viability of the larva and pupa stages; number and duration of instars, pupal weight, sex ratio; preoviposition, oviposition and postoviposition periods and male and female longevity were obtained from evaluations twice a day (9:00 AM and 03:00 PM) under a stereomicroscope, the change of stage being determined by the presence and measurement of the head capsule.

A t-test $(\mathrm{P}=0.05)$ was used to compare males and females with respect to the duration of different biological cycle stages. Statistical analyses were performed with the System of Statistical and Genetic Analysis (SAEG) of the Federal University of Viçosa.

\section{Results}

The eggs of $C$. teucer japetus are spherical $(1.83 \pm 0.05 \mathrm{~mm}$ in diameter) with a number of vertical carina ranging from 28 to 30 , carved in the shell forming lateral lobes that start from the micropylar region at the upper pole. These eggs, initially whitish, turn milky and dark white next to the caterpillar hatching (Fig. 1A). The incubation period and viability of eggs were similar for caterpillars that originated males or females (Table 1).
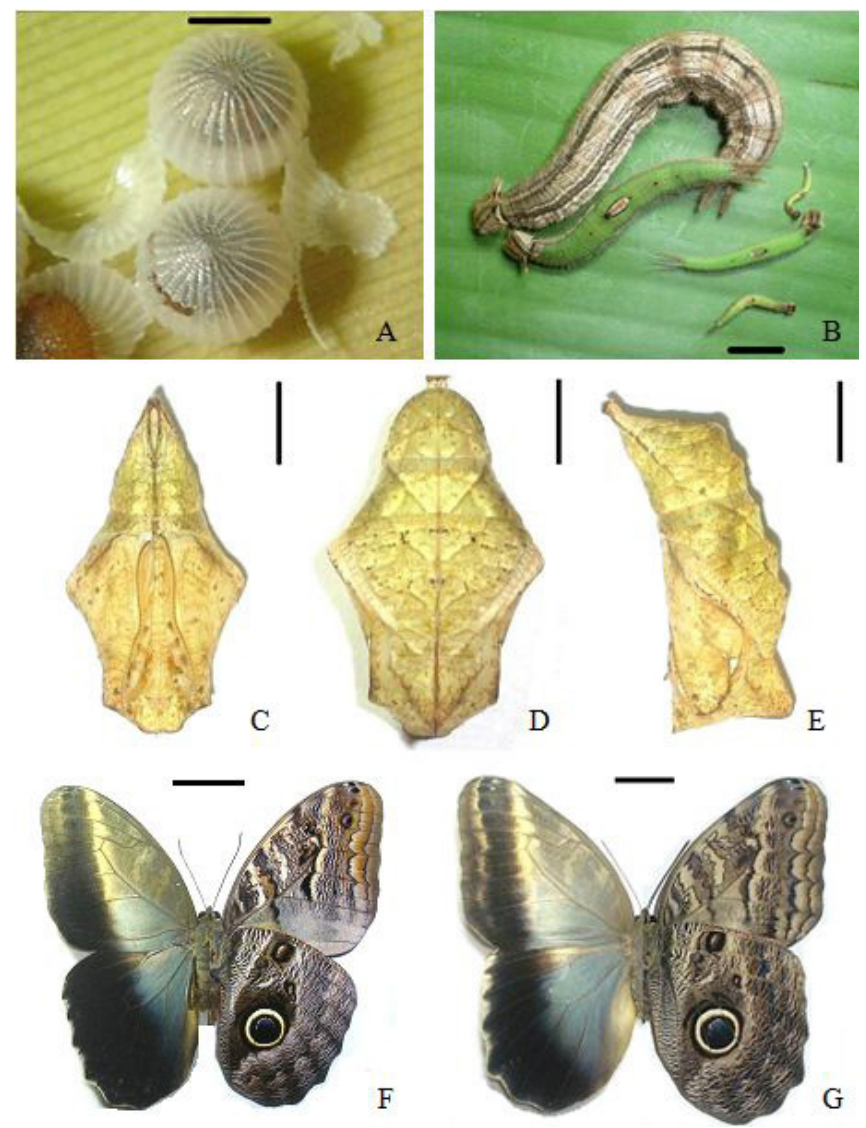

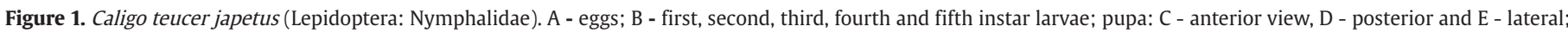
F - male, dorsal (left), ventral (right); G - female, dorsal (left), ventral (right) view. Scale bars A, B: $1 \mathrm{~mm}, \mathrm{C}, \mathrm{D}, \mathrm{E}: 10 \mathrm{~mm}, \mathrm{~F}, \mathrm{G}: 20 \mathrm{~mm}$. 
Table 1

Survival and duration (mean \pm standard error) of the stages and instars of Caligo teucer japetus (Lepidoptera: Nymphalidae) in cages with Musa sapientium leaves at a temperature of $24 \pm 1{ }^{\circ} \mathrm{C}$, relative humidity of $68 \pm 10 \%$ and 12 hours photophase. Viçosa, Minas Gerais, Brazil.

\begin{tabular}{|c|c|c|c|c|c|c|c|}
\hline \multirow{2}{*}{ Stage } & \multirow{2}{*}{$\begin{array}{c}\text { Survival } \\
(\%)\end{array}$} & \multicolumn{6}{|c|}{ Duration } \\
\hline & & Female & $\mathrm{n}$ & Male & $\mathrm{n}$ & Female + Male & $\mathrm{n}$ \\
\hline Egg & 86.11 & $11.84 \pm 0.14$ & 38 & $11.84 \pm 0.14^{\mathrm{n} . \mathrm{s}}$ & 38 & $11.84 \pm 0.00$ & 76 \\
\hline Larva & 68.00 & $53.91 \pm 0.91$ & 27 & $50.34 \pm 0.64^{*}$ & 25 & $52.18 \pm 0.62$ & 52 \\
\hline First Instar & 68.42 & $10.00 \pm 0.73$ & 27 & $8.69 \pm 0.38^{\text {n.s }}$ & 25 & $9.38 \pm 0.43$ & 76 \\
\hline Second Instar & 100.00 & $9.11 \pm 0.41$ & 27 & $8.34 \pm 0.24^{\text {n.s. }}$ & 25 & $8.75 \pm 0.25$ & 52 \\
\hline Third Instar & 100.00 & $8.92 \pm 0.43$ & 27 & $8.94 \pm 0.18^{\text {n.s. }}$ & 25 & $8.93 \pm 0.24$ & 52 \\
\hline Fourth Instar & 100.00 & $9.89 \pm 0.22$ & 27 & $9.44 \pm 0.26^{\text {n.s. }}$ & 25 & $9.68 \pm 0.17$ & 52 \\
\hline Fifth Instar & 100.00 & $16.94 \pm 0.32$ & 27 & $14.94 \pm 0.34^{*}$ & 25 & $16.00 \pm 0.29$ & 52 \\
\hline Pupa & 98.07 & $17.88 \pm 0.34$ & 26 & $18.40 \pm 0.27^{\mathrm{n} . \mathrm{s}}$ & 25 & $18.13 \pm 0.22$ & 51 \\
\hline Egg-adult & 100.00 & $82.58 \pm 0.95$ & 16 & $79.43 \pm 0.64$ & 16 & $81.86 \pm 0.59$ & 51 \\
\hline
\end{tabular}

${ }^{n s}$ Not significant at $5 \%$ probability by the "t" test. "Significant at $5 \%$ probability by the " $t$ " test. $n$ : number of individuals.

Table 2

Longevity (mean \pm standard error) of adults of Caligo teucer japetus (Lepidoptera: Nymphalidae) in cages and butterfly houses. Viçosa, Minas Gerais, Brazil.

\begin{tabular}{|c|c|c|c|c|c|c|}
\hline \multirow{2}{*}{ Stage } & \multicolumn{2}{|c|}{ Survival } & \multicolumn{4}{|c|}{ Longevity } \\
\hline & ${ }^{2} \mathrm{n}$ & $(\%)$ & Female & ${ }^{2} \mathrm{n}$ & Male & ${ }^{2} \mathrm{n}$ \\
\hline & & & & & & \\
\hline \multirow[t]{2}{*}{ Adult } & 20 & 100 & $26.0 \pm 3.4$ & 10 & $24.7 \pm 1.2^{\mathrm{ns}}$ & 10 \\
\hline & \multicolumn{6}{|c|}{ Butterfly garden } \\
\hline Adult & 20 & 100 & $47.5 \pm 1.0$ & 10 & $35.4 \pm 0.6^{*}$ & 10 \\
\hline
\end{tabular}

${ }^{n}$ Not significant at $5 \%$ probability by the " $t$ " test. "Significant at $5 \%$ probability by the " $t$ " test. ${ }^{2} n$ : number of individuals.

The duration of each instar of $C$. teucer japetus caterpillars varied between them and sex (Table 1), with lower value in the third instar for both sexes and longer in the fifth for caterpillars that originated females. The width of the head capsules and the body length of the first, second, third, fourth and fifth instars $C$. teucer japetus were 1.33 $\pm 0.01 \mathrm{~mm}$ and $10.84 \pm 0.36 \mathrm{~mm} ; 1.98 \pm 0.01 \mathrm{~mm}$ and $18.29 \pm 0.62 \mathrm{~mm}$; $2.91 \pm 0.02 \mathrm{~mm}$ and $32.83 \pm 0.91 \mathrm{~mm} ; 4.50 \pm 0.03$ and $65.23 \pm 1.32 \mathrm{~mm}$; $6.55 \pm 0.06$ and $87.77 \pm 1.91 \mathrm{~mm}$, respectively (Fig. 1B). Some caterpillars reached $16,24,44,74$ and $115 \mathrm{~mm}$ long in the first, second, third, fourth and fifth instars, respectively.

The longevity of the $C$. teucer japetusimmatures was shorter for the larvae and longer for the pupa, and the duration of these stages varied between them and sex (Table 2), with greater and lesser value for the larvae and egg, respectively, and longer larval period for individuals that originated females.

The durations of the larval stage and the egg to adult period of C. teucer japetus were longer for individuals that originated females (Table 1), but those of pupa were similar between sexes.

The weight of $C$. teucer japetus pupae differed between sexes, with females being heavier than males. The pupa of this insect (Fig. 1C, D, E) is obtecte, with yellow to brown-yellow coloration, several bands and streaks of dark brown color, in addition to a narrow brown color band on the dorsal part, from the vertex to the cremaster. The pupal length was $42.0 \pm 0.17 \mathrm{~mm}$.

The duration of the pre-oviposition, oviposition and post-oviposition periods of $C$. teucer japetus females, kept in cages, were, respectively, $12.86 \pm 1.74$ days; $4.86 \pm 1.42$ days and $6.71 \pm 2.06$ days, with oviposition of $12.0 \pm 2.9$ eggs per female.

The $C$. teucer japetus female longevity was longer and similar to that of males in both environmentals (Table 2), but that of both sexes was lower in cages than in the butterfly garden. The periods of preoviposition, oviposition, postoviposition and fecundity could not be evaluated for the butterfly garden individuals.

The $C$. teucer japetus adult (Fig. 1F, G) is a butterfly with the dorsal part of the wings with a blue-gray color and the outer edges with a wide black band. Males (Fig. 1F) measure $61.9 \pm 19.6 \mathrm{~mm}$ in wingspan with the anterior dorsal region of the first pair of wings light yellow, blue from the first anal vein and external edges with a large black band. The females (Fig. 1G) are larger, with $154.8 \pm 48.9 \mathrm{~mm}$ of wingspan with the anterior dorsal portion of the first pair of wings light yellow and lighter blue and the outer edges with a thinner black band in relation to males. The ventral face of the wings, of both sexes, is predominantly brown, with a black ocellar patch of white halo in the center of the pair of posterior wings, which gave rise to the name of owl butterfly for species of this genus.

\section{Discussion}

The egg size and the carinae number of $C$. teucer japetus are within the range of 1.8-2.0 $\mathrm{mm}$ and 28-30 carinas, respectively, for $C$. teucer (Souza et al., 2006), but greater than the 26-27 carinae of $C$. eurilochus (Cramer, 1775) and lower than the 31 and 33-36 of $C$. beltrao (Illiger, 1801) (Casagrande, 1979) and C. illioneus (Cramer, 1775) (Specht and Paluch, 2009), respectively. The darkening of the $C$. teucer japetus eggs is due to the semitransparent corium showing the color of the head and the longitudinal carmine red stripes of the pre-emergent caterpillar (Souza et al., 2006). The egg viability of $C$. teucer japetus females, originated from caterpillars fed with banana leaves was three times greater than that of $C$. illioneus with leaves of this plant, which may be due to the conditions of each experiment and the variations between species of this genus. The $C$. teucer japetus eggs were kept in climatic chambers with constant temperature and relative humidity, while those of $C$. illioneus were kept with banana leaves under uncontrolled temperature and humidity (Penz et al., 1999).

The egg incubation period, for females originated from caterpillars fed with banana leaves, was longer than the six days of $C$. illioneus with leaves of this plant (Penz et al., 1999) and 8.9 days for C. eurilochus brasiliensis (C. Felder, 1862) with leaves of Saccharum spontaneum L. (Poaceae) and Cyrtostachus sp. (Araceae) (Malo and Willis, 1961). These variations may be because the eggs were kept at a temperature lower than $25-29 \stackrel{\circ}{\circ} \mathrm{C}$ from that of $C$. illioneus (Penz et al., 1999) and C. eurilochus brasiliensis (Malo and Willis, 1961). 
Variations in the duration of each instar and sex, of individuals fed with banana leaves, may be related to the higher leaf consumption by these caterpillars as they develop (Llandres et al., 2015) and the fact that those that originated females need more nutritional resources, because they are, on average, larger than those that originated males (Specht et al., 2013). The shorter duration of the third and longer of the fifth instar of $C$. teucer japetus, with banana leaves, is also due to the increase in the feeding period, in the latter, to accumulate lipids necessary for the pupa formation (Mevi-Schütz and Erhardt, 2003; Llandres et al., 2015). On the other hand, the longer durations of the first, second, third, fourth and fifth instars of $C$. teucer japetus compared to those of $C$. illioneus with leaves of Heliconia velloziana (Heliconiaceae) (Specht and Paluch, 2009); that of the first (6 days), second ( 8 days), third ( 5 days), fourth (5-6 days) and fifth (6-7) instars of $C$. illioneus with banana leaves (Penz et al., 1999) and the first (7.7 days), second (7.5 days) and third (8.6 days) instars of C. eurilochus with S. spontaneum and Cyrtostachus sp. leaves (Malo and Willis, 1961) can be attributed to the variations between Caligo species, their host plants (War et al., 2012, 2018; Santamaria et al., 2015, 2018) and the development temperature of these caterpillars (Solensky and Larkin, 2003; Navarro-Cano et al., 2015).

The cephalic capsule widths and the maximum length of the first, second, third, fourth and fifth instar larva of of $C$. teucer japetus caterpillars are within the range, for these parameters, of $1.3-1.5 \mathrm{~mm}$; $1.8-2.4 \mathrm{~mm} ; 2.6-3.1 \mathrm{~mm} ; 4.2-4.7 \mathrm{~mm}$ and $6.6-7.4 \mathrm{~mm}$ and $20 \mathrm{~mm}, 32 \mathrm{~mm}$, $46 \mathrm{~mm}, 69 \mathrm{~mm}$ and $125 \mathrm{~mm}$ when fed with Heliconia bihai (Heliconiaceae), Canna indica (Cannaceae) and Alpinia purpurata (Zingiberaceae) leaves (Souza et al., 2006).

The lower survival of $C$. teucer japetus caterpillars is probably due to their gregarious behavior from the first to the fourth instar (Specht and Paluch, 2009; Allen, 2010), with higher mortality from those of the first instar, individualized, and therefore more vulnerable to chemical and morphological defenses of banana leaves (Reader and Hochuli, 2003; Campbell and Stastny, 2015) and the leaves microclimate (Ronnas et al., 2010; Campbell and Stastny, 2015). In addition, the metabolism, digestive physiology and intestinal microbiote of newborn caterpillars differ from those in more advanced instars (Mason and Raffa, 2014; Despland, 2018), being more selective and sensitive to food and plant chemical defenses, possibly due to a more limited set of digestive enzymes (Hochuli, 2001). The survival of 100\%, in the instars, except for the first, of $C$. teucer japetus was similar to that of $C$. illioneus caterpillars fed with banana leaves (Penz et al., 1999), indicating that this substrate is suitable for these insects.

The longer and shorter duration of the larvae and egg stages, respectively, is commom for species of the genus Calligo (Penz et al., 1999; Souza et al., 2006; Specht and Paluch, 2009) and, as mentioned, the longest larval period of individuals that originated females can be attributed to the fact that females need more nutritional resources than males to reach adulthood (Specht et al., 2013). The greater duration of the larval stage of $C$. teucer, of individuals that originated females, is due to its greater weight or size in relation to males. This is due to the fact that the weight and size of larvae are positively correlated with the fitness parameters (egg production), whose females hatch from the pupa with preformed and formed eggs and, therefore, need a longer larval period of time to produce pupa (Tammaru, 1998; Gotthard, 2008). This may explain the similar duration of the pupa stages, between the sexes, because the pupation depends on the biomass gained during the immature stage; if a caterpillar is in its final instar with a low weight, it is necessary to evaluate the potential cost of a longer development and the that of reduced adult weight (Slansky, 1980).

The duration of the larvae and pupa stages and the egg-adult period of $C$. teucer japetus were similar to the values of 51.5, 18.1 and
78.1 days, respectively, for $C$. eurilochus fed with $S$. spontaneum and Cyrtostachus sp. leaves (Malo and Willis, 1961), greater than the 32, 13 and 45 days, respectively, of $C$. illioneus fed with $H$. velloziana leaves (Specht and Paluch, 2009) and that of the 46.5, 14 and 67 days with banana leaves (Penz et al., 1999). These differences indicate, once again, that the duration of the larvae, pupa and egg stages vary with the Caligo species and with the host plant and temperature.

The higher weight of $C$. teucer japetus pupae, which originated females in relation to those that originated males, can be attributed to the greater lipid accumulation for the reproductive activities of females that are larger and with a longer development period (Ziegler and Van Antwerpen, 2006; Specht et al., 2013). The pupae of $C$. teucer and $C$. illioneus are very similar, which difficults their identification (Specht and Paluch, 2009). The length of $C$. teucer japetus pupae was longer than those of $C$. illioneus (37-40 mm)(Specht and Paluch, 2009) and similar to those of $C$. teucerfed with three host plants (39-42 mm) (Souza et al., 2006).

The longer and shorter duration, respectively, of $C$. teucer japetus female preoviposition and oviposition periods, in cages in the laboratory, differed from the general pattern for lepidopterans (Specht et al., 2013; Martínez et al., 2014). This indicates that the food offered to adults in the cages partially met their nutritional needs, which also affect their mating behavior and posture (Geister et al., 2008; Hiroyoshi and Reddy, 2018).

The longer longevity of females than males of $C$. teucer japetus in the butterfly garden maybe related to the stress caused on adults confined in cages (Bronikowski and Promislow, 2005; Molleman et al., 2007; Niitepõld, 2019). This may explain the greater adult longevity of both sexes in the butterfly garden, where they could feed on fermented fruits but, also on the plant sap, manure and mineral salts in water pools (Srygley and Penz, 1999). These longevities, in cages and in the butterfly garden, were shorter and longer, respectively, than the 28.5 days and 28 days of $C$. brasiliensis and $C$. illioneus in the laboratory (Silva et al., 2013).

The sexual dimorphism of $C$. teucer japetus, in size and color, is a general pattern among butterflies of this genus, with males, in most cases, being smaller and with a more intense and bright color than females. This is because females are more sensitive to intraspecific color variations, choosing males with bright iridescent ornamentation (Kemp, 2007).

The results obtained in this research allow concluding that the number of instars of Caligo teucer japetus was five with high survival. The gregarious behavior of its larvae and the relatively short development period confirm the potential of this butterfly as a pest of the banana tree.

\section{Acknowledgments}

We thank the Prof. Olaf H. H. Mielke of the Department of Zoology at the Federal University of Paraná, Paraná State, Brazil, for confirming the species of Caligo and revising the manuscript.

\section{Funding}

Financial support were provided by Conselho Nacional de Desenvolvimento Científico e Tecnológico (CNPQ), Coordenação de Aperfeiçoamento de Pessoal de Nível Superior (CAPES), Fundação de Amparo à Pesquisa do Estado de Minas Gerais" and "Programa Cooperativo sobre Proteção Florestal (PROTEF) do Instituto de Pesquisas e Estudos Florestais (IPEF)" for financial support. 


\section{Conflicts of interest}

The authors declare that they have no conflict of interest

\section{Author contribution statement}

All authors contributed in the design of the project. Experiments and analysis were performed by CADS and FFP supported by JCZ. CADS, JCZ, WMS, LCM, FFP and GLDL drafted the manuscript, and all authors contributed to the writing and final version of the manuscript.

\section{References}

Allen, P. E., 2010. Group size effects on survivorship and adult development in the gregarious larvae of Euselasia chrysippe (Lepidoptera, Riodinidae). Insectes Soc. 57, 199-204.

Almeida, J.A., Gherardi, S.R.M., 2018. Trufa de chocolate meio amargo com biomassa de banana verde. Multi-Science J. 1, 45-47.

Arroyo, A., Rodriguez, M., 2005. Informe técnico situación del cultivo de banana en la región subtropical de Salta-Jujuy. Yuto, INTA, Agencia de Extensión Rural Orán, 5 p.

Bauerfeind, S. S., Fischer, K., Hartstein, S., Janowitz, S., Martin-Creuzburg, D., 2007. Effects of adult nutrition on female reproduction in a fruit-feeding butterfly: the role of fruit decay and dietary lipids. J. Insect Physiol. 53, 964-973.

Blandin, P., Descimon, H., 1975. Contribution a la connaissance des lépidoptères des l'Équateur les Brassolinae (Nymphalidae). Ann. Soc. Entomol. Fr. 11, 3-28.

Bronikowski, A.M., Promislow, D.E.L., 2005. Testing evolutionary theories of aging in wild populations. Trends Ecol. Evol. 20, 271-273.

Campbell, S.A., Stastny, M., 2015. Benefits of gregarious feeding by aposematic caterpillars depend on group age structure. Oecologia 177, 715-721.

Casagrande, M.M., 2002. Naropini Stichel, taxonomia e imaturos (Lepidoptera, Nymphalidae, Brassolinae). Rev. Bras. Zool. 19, 467-569.

Casagrande, M. M., 1979. Sobre Caligo beltrao (Illiger). I. Taxonomia, biologia, morfologia das fases imaturas e distribuições espacial e temporal (Lepidoptera, Satyridae, Brassolinae). Rev. Bras. Biol. 39, 173-193.

Casagrande, M.M., Mielke, O.H.H., 2000. Larva de quinto estádio e pupa de Caligo martia (Godart) (Lepidoptera, Nymphalidae, Brassolinae). Rev. Bras. Zool. 17, 65-74.

Casagrande, M.M., Mielke, O.H.H., 2008. A note on the life history of Caligo brasiliensis brasiliensis (Lepidoptera: Nymphalidae: Morphinae). Trop. Lepid. Res. 18, 9-11.

Despland, E., 2018. Effects of phenological synchronization on larvae early-instar survival under a changing climate. Can. J. For. Res. 48, 247-254.

Devries, P.J., Walla, T.R., 2001. Species and community structure in neotropical fruit-feeding butterflies. Biol. J. Linn. Soc. Lond. 74, 1-15.

Fancelli, M., 2012. Metamasius hemipterus L. como praga de bananeiras cv. Terra. Rev. Bras. Fruticultura 34, 944-946.

Freitas, A.V.L., Brown Junior, K.S., 2004. Phylogeny of the Nymphalidae (Lepidoptera: Papilionoidea). Syst. Biol. 53, 363-383.

Geister, T.L., Lorenz, M.W., Hoffmann, K.H., Fischer, K., 2008. Adult nutrition and butterfly fitness: effects of diet quality on reproductive output, egg composition, and egg hatching success. Front. Zool. 5, 10.

Gotthard, K., 2008. Adaptive growth decisions in butterflies. Bioscience 58, 222-230.

Hiroyoshi, S., Reddy, G.V.P., 2018. Field and laboratory studies on the ecology, reproduction, and adult diapause of the Asian comma butterfly, Polygonia c-aureum L. (Lepidoptera: nymphalidae). Insects 9, 169.

Hochuli, D.F., 2001. Insect herbivory and ontogeny: how do growth and development influence feeding behaviour, morphology and host use? Austral Ecol. 26, 563-570.

Instituto Brasileiro de Geografia e Estatística - IBGE, 2020. IBGE: levantamento sistemático da produção agrícola. Available in: https://sidra.ibge. gov.br/home/lspa/brasil (accessed 19 July 2020).

Kemp, D.J., 2007. Female butterflies prefer males bearing bright iridescent ornamentation. Proc. R. Soc. B. 274, 1043-1047.

Labou, B., Brévault, T., Sylla, S., Diatte, M., Bordat, D., Diarra, K., 2017. Spatial and temporal incidence of insect pests in farmers' cabbage fields in Senegal. Int. J. Trop. Insect Sci. 37, 225-233.

Llandres, A.L., Marques, G.M., Maino, J.L., Kooijman, S.A.L.M., Kearney, M.R., Casas, J., 2015. A dynamic energy budget for the whole lifecycle of holometabolous insects. Ecol. Monogr. 83, 353-371.

Malo, F., Willis, E.R., 1961. Life history and biological control of Caligo eurilochus, a pest of banana. J. Econ. Entomol. 54, 530-536.

Martínez, L.C., Plata-Rueda, A., Zanuncio, J.C., Ribeiro, G.T., Serrão, J.E., 2014. Effects of temperature on the development of Stenoma impressella (Lepidoptera: Elachistidae) on oil palm in Colombia. Fla. Entomol. 97 (4), 1805-1811.

Mason, C.J., Raffa, K.F., 2014. Acquisition and structuring of midgut bacterial communities in gypsy moth (Lepidoptera: Erebidae) larvae. Environ. Entomol. 43, 595-604.

Mevi-Schütz, J., Erhardt, A., 2003. Mating frequency influences nectar amino acid preference of Pieres napi. Proc. Biol. Sci. 271, 153-158.

Mielke, O.H.H., Casagrande, M.M., 2006. Catálogo bibliográfico dos taxa superiores de ordem Lepidoptera. Rev. Bras. Zool. 23, 1-41.

Molleman, F., Zawaan, B.J., Brakefield, P.M., Carey, J.R., 2007. Extraordinary long life spans in fruit-feeding butterflies can provide window on evolution of life span and aging. Exp. Gerontol. 42, 472-482.

Navarro-Cano, J.A., Karlsson, B., Posledovich, D., Toftegaard, T., Wiklund, C., Ehrlén, J., Gotthard, K., 2015. Climate change, phenology and butterfly host plant utilization. Ambio 44, 78-88.

Niitepõld, K., 2019. Effects of flight and food stress on energetics, reproduction, and lifespan in the butterfly Melitaea cinxia. Oecologia 191, 271-283.

Okolle, J.N., Abu Hassan, A., Mashhor, M., 2011. Evaluation of selected insecticides for managing larvae of Erionota thrax and effects on its parasitoid (Brachymeria albotibialis). Pest Technolology 5, 39-43.

Ostmark, H.E., 1974. Economic insect pests of bananas. Annu. Rev. Entomol. 19, 161-176.

Penz, C.M., 2007. Evaluating the monophyly and phylogenetic relationships of Brassolini genera (Lepidoptera, Nymphalidae). Syst. Entomol. 32, 668-689.

Penz, C.M., Aiello, A., Srygley, R.B., 1999. Early stages of Caligo illioneus and Caligo idomeneus (Nymphalidae, Brassolinae) from Panama, with remarks on larval food plants for the subfamily. J. Lepid. Soc. 53, 142-152.

Ramos, F.A., 2000. Nymphalid butterfly communities in an amazonian forest fragment. J. Res. Lepid. 35, 29-41.

Reader, T., Hochuli, D.F., 2003. Understanding gregariousness in a larval Lepidopteran: the roles of host plant, predation, and microclimate. Ecol. Entomol. 28, 729-737.

Ronnas, C., Larsson, S., Pitacco, A., Battisti, A., 2010. Effects of colony size on larval performance in a processionary moth. Ecol. Entomol. 35, 436-445.

Santamaria, M.E., Arnaiz, A., Diaz-Mendoza, M., Martinez, M., Diaz, I., 2015. Inhibitory properties of cysteine protease pro-peptides from barley confer resistance to spider mite feeding. PLoS ONE 10, e0128323. 
Santamaria, M.E., Arnaiz, A., Gonzalez-Melendi, P., Martinez, M., Diaz, I., 2018. Plant perception and short-term responses to phytophagous insects and mites. Int. J. Mol. Sci. 19, 2-20.

Silva, A.R.M., Pimenta, I.A., Campos-Neto, F.C., Vitalino, R.F., 2013. Longevidade de adultos de oito espécies de borboletas (Lepidoptera: Papilionoidea) criadas em cativeiro. Lundiana 11, 65-67.

Silva, J.R., Cordeiro, Z.J.M., 2000. Fitossanidade na exportação da banana. In: Cordeiro, Z.J.M. (Org.). Frutas do Brasil: banana fitossanidade. Embrapa CTT, Brasília.

Slansky Junior, F., 1980. Quantitative food utilization and reproductive allocation by adult milkweeds bugs, Oncopeltus fasciatus. Physiol. Ent. 5 (1), 395-403.

Smilanich, A.M., Dyer, L.A., 2012. Effects of banana plantation pesticides on the immune response of lepidopteran larvae and their parasitoid natural enemies. Insects 3, 616-628.

Solensky, M.J., Larkin, E., 2003. Temperature-induced variation in larval coloration in Danaus plexippus (Lepidoptera: nymphalidae). Ann. Entomol. Soc. Am. 96, 211-216.

Souza, N.A., Veiga, A.F.S.L., Casagrande, M.M., Gondim Junior, M.G.C., 2006. Morfologia externa dos imaturos de Caligo teucer(Linnaeus) (Lepidoptera, Nymphalidae). Rev. Bras. Zool. 23, 1243-1250.

Specht, A., Angulo, A.O., Olivares, T.S., Fronza, E., Roque-Specht, V.F., Valduga, E., Albrecht, F., Poletto, G., Barros, N. M., 2013. Life cycle of
Agrotis malefida(Lepidoptera: Noctuidae): a diapausing cutworm. Zoologia 30, 371-378.

Specht, M.J.S., Paluch, M., 2009. Estágios imaturos de Caligo illioneus illioneus (Cramer) (Nymphalidae: Morphinae: Brassolini). Neotrop. Entomol. 38, 801-808.

Srygley, R.B., Penz, M.P., 1999. Lekking in neotropical owl butterflies, Caligo illioneus and $C$. oileus (Lepidoptera: brassolinae). J. Insect Behav. 12, 81-103.

Tammaru, T., 1998. Determination of adult size in a folivorous moth: constraints at instar level? Ecol. Ent. 23, 80-89.

Wahlberg, N., Weingartner, E., Nylin, S., 2003. Towards a better understanding of the higher systematics of Nymphalidae (Lepidoptera: Papilionoidea). Mol. Phylogenet. Evol. 28, 473-484.

War, A.R., Paulraj, M.G., Ahmad, T., Buhroo, A.A., Hussain, B., Ignacimuthu, S., Sharma, H.C., 2012. Mechanisms of plant defense against insect herbivores. Plant Signal. Behav. 7, 1306-1320.

War, A.R., Taggar, G.K., Hussain, B., Taggar, M.S., Nair, R.M., Sharma, H.C., 2018. Plant defence against herbivory and insect adaptations. AoB Plants 10, 1-19.

Ziegler, R., Van Antwerpen, R.V., 2006. Lipid uptake by insect oocytes. Insect Biochem. Mol. 36, 264-272. 